\title{
IMPACT OF CLIMATE CHANGE ON THE GEOGRAPHICAL DISTRIBUTION OF A CLOUD FOREST INDICATOR TREE SPECIES
}

\author{
Guilherme Neto dos Santos ${ }^{2} \cdot$, Ana Carolina da Silva ${ }^{3} \cdot$ and Pedro Higuchi ${ }^{*}$
}

\author{
${ }^{1}$ Received on 31.03.2020 accepted for publication on 12.08.2020. \\ ${ }^{2}$ Universidade Do Estado de Santa Catarina, Programa de Pós-Graduação em Engenharia Florestal, Florianópolis, SC-Brasil. E-mail: \\ <guineto.florestal@gmail.com>. \\ ${ }^{3}$ Universidade Do Estado de Santa Catarina, Centro Agroveterinário , Lages, SC-Brasil. E-mail: <carol_sil4@yahoo.com.br>and \\ $<$ higuchip@gmail.com>. \\ *Corresponding author.
}

\begin{abstract}
The cloud forests are threatened due to the climate change process. Investigations seeking to predict how future climate change will affect species are of great importance as they are fundamental to generating conservation strategies. We aimed to detect how climate change affects the potential geographical distribution of Drimys angustifolia Miers, a tree species that is an indicator of the upper-montane cloud forest in the Brazilian subtropical Atlantic Forest. The areas where D. angustifolia occurs were obtained from geographic coordinates available in scientific publications and the Global Biodiversity Information database. For climate niche modeling, we used the maximum entropy algorithm with 19 climate variables. Two climate change scenarios were considered for 2061-2080: one of low and one of high impact. D. angustifolia predominantly occurs in the upper-montane forests and is absent from dry and warm sites. The variables that best explained the $D$. angustifolia climatic niche were mean temperature of the warmest quarter, precipitation of driest month, and precipitation of the warmest quarter. Both scenarios indicated changes towards a more tropical regional future climate. Under the low impact climate change scenario, D. angustifolia coverage declined by $68.24 \%( \pm$ $7.32 \%)$ across its area of potential occurrence; it declined by $79.15 \%( \pm 9.65 \%)$ under the high impact scenario. In conclusion, the results of the present study showed that D. angustifolia and its associated ecosystem are threatened by the potential impacts of future climate change. Consequently, we highlight climatically stable areas for the occurrence of $D$. angustifolia, such as those located in the highest parts of the mountain ranges of the southern and southeastern regions of Brazil, which should be considered as priority areas for protection and conservation.
\end{abstract}

Keywords: Climate variable; Drimys angustifolia; Upper-montane cloud forest.

\section{IMPACTO DAS MUDANÇAS CLIMÁTICAS NA DISTRIBUIÇÃO GEOGRÁFICA DE UMA ESPÉCIE ARBÓREA INDICADORA DE FLORESTA NEBULAR}

RESUMO - As florestas nebulares estão ameaçadas devido ao processo de mudanças climáticas. Investigações que buscam prever como estas mudanças afetarão as espécies são de grande importância, pois são fundamentais para gerar estratégias de conservação. Assim, objetivamos detectar como as mudanças climáticas afetarão a distribuição geográfica potencial de Drimys angustifolia Miers, uma espécie arbórea indicadora da floresta nebular na Mata Atlântica subtropical brasileira. As áreas de ocorrência de D. angustifolia foram obtidas a partir de coordenadas geográficas disponiveis em publicações científicas e no banco de dados Global Biodiversity Information. Para a modelagem de nicho climático, usamos o Algoritmo de Máxima Entropia, com 19 variáveis climáticas. Dois cenários de mudanças climáticas foram considerados para o período 2061-2080: um de baixo e outro de alto impacto. D. angustifolia ocorre, predominantemente, nas florestas alto-montanas e está ausente em locais quentes e secos. As variáveis que melhor explicaram o nicho climático de D. angustifolia foram temperatura média no trimestre mais quente, precipitação no mês mais seco e precipitação no trimestre mais quente. Ambos os cenários indicaram mudanças em direção a um clima futuro regional mais tropical. No cenário de baixo impacto de mudanças climáticas, a cobertura de D. angustifolia reduziu $68,24 \%( \pm 7,32 \%)$ em sua área de ocorrência potencial; e diminuiu 79,15\% ( $\pm 9,65 \%)$ no cenário de alto impacto. Os resultados nos permitem concluir que D. angustifolia e seu ecossistema associado estão ameaçados pelos possíveis

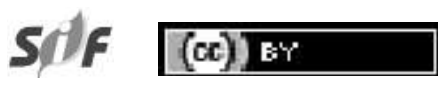

Revista Árvore 2020;44:e4432

http://dx.doi.org/10.1590/1806-908820200000032 
impactos das futuras mudanças climáticas. Assim, destacamos áreas climáticas estáveis para a ocorrência de D. angustifolia, como as localizadas nas partes mais altas das cadeias montanhosas das regiões Sul e Sudeste do Brasil, que devem ser consideradas áreas prioritárias para proteção e conservação.

Palavras-Chave: Variável climática; Drimys angustifolia; Floresta nebular alto-montana.

\section{INTRODUCTION}

According to projections from the Fifth Assessment Report of the Intergovernmental Panel on Climate Change (IPCC), global temperatures will rise by up to $4.8^{\circ} \mathrm{C}$, on average, by the year 2100 (IPCC, 2014). There is evidence of strong warming in recent decades, with temperature rise exceeding that registered since 1861 when instrumental records began (IPCC, 2001). Consequently, several impacts of climate change on the planet's ecosystems have already been reported (Walther et al., 2002). Thus, investigations seeking to predict how future climate change will affect biological communities are of great importance as they are fundamental to generating mitigation strategies, including the identification of refuge areas, the protection of threatened populations, and assisted dispersal (Hoegh-Guldberg et al., 2008).

Recent studies (Becker-Scarpitta et al., 2019; Boisvert-Marsh et al., 2019) have shown that one of the main responses of species to the global warming process is a shift in their respective naturally occurring distribution, with displacement towards the poles and to areas of higher altitude. This phenomenon occurs because the geographical distribution of a given species is determined by its physiological limits, which are related to temperature tolerance and precipitation (Walther et al., 2002). Consequently, plant species that are already restricted to higher altitudes are at greatest risk, with the upper-montane cloud forests representing terrestrial ecosystems that may be strongly impacted by climate changes (Forster, 2001). Because of environmental filters such as low temperatures, these forest ecosystems have a selective environment that limits the number of species that are able to thrive, reflected in an idiosyncratic floristic composition (Higuchi et al., 2013). Thus, in the face of a range of potential climate change scenarios, biological composition is expected to change in the upper-montane cloud forests, as a result of the arrival of species from lower altitudes and extinction of endemic species in high elevation areas (Foster, 2001).

The upper-montane cloud forests situated in the subtropical part of the Brazilian Atlantic Forest represent part of a global biodiversity hotspot (Myers et al., 2000). Despite having a smaller diversity of species compared with locations at lower altitudes, these areas present a unique set of endemic species (Higuchi et al., 2012). Besides being subject to the impacts of climate change, these forests are also susceptible to forest fragmentation and other chronic anthropogenic disturbances (Higuchi et al., 2013). According to the Brazilian vegetation classification system (IBGE, 2012), these forests appear above $1,000 \mathrm{~m}$ altitude.

In this study, we aimed to predict how climatic change will affect this important ecosystem type, which is characterized by high endemism and has important environmental functions, such as soil and water course protection (Martínez et al., 2009). We modelled the climate niche of Drimys angustifolia Miers, a species that exhibits a high affinity with this type of forest formation. Subsequently, we projected current and future areas of climatic suitability for this species. We hypothesized that there will be a reduction in the potential distribution area for $D$. angustifolia because this species is restricted to sites located at the highest altitudes. Our results are expected to provide baseline information to develop viable conservation strategies, such as the selection of conservation areas that could potentially serve as a climate refuge.

\section{MATERIAL AND METHODS}

We carried out a bibliographic review of published studies to select the species that had the highest affinity with the upper-montane cloud forest of the subtropical portion of the Brazilian Atlantic Forest. We considered two criteria: i) the study area should be a cloud forest; and ii) the study area should be part of the subtropical portion of the upper-montane Atlantic Forest. For i), in addition to existing knowledge of some of these forests, we assumed that these areas should have cloud coverage above $60 \%$, according to Wilson and Jetz (2016). For ii), according to the Brazilian system of vegetation classification (IBGE, 2012), the area must have an altitude above $1,000 \mathrm{~m}$ and be located to the south of the Tropic of Capricorn. We found 26 studies (https://figshare.com/s/b56bf1877a40fc18894f) that

Revista Árvore 2020;44:e4432 
met these criteria. D. angustifolia was present in 15 areas and was selected as an indicator species because it has a broad distribution in the specified areas and predominantly occurs at the highest points of southern Brazil (https://figshare.com/s/0ad8dd97528c3403b25f). According to Hertzog et al. (2016), in Rio Grande do Sul State, in southern Brazil, D. angustifolia occurs from 700 to $1,400 \mathrm{~m}$ altitude. Furthermore, observations of its geographical area of distribution show that this species has a higher occurrence above 1,000 m altitude (Martins et al., 2012; Silva et al., 2017). Although other listed species are also frequently found in high montane cloud forests, what makes D. angustifolia unique is that it is mostly found exclusively in such environments (Uhlmann et al., 2013), besides being locally present in high abundance (Higuchi et al., 2013).

To complement the occurrence data for $D$. angustifolia obtained from the literature review, we also used information about geographical distribution provided by the GBIF database (GBIF Secretariat, 2017; GBIF.org, 2019). All coordinates were checked to find inconsistencies such as typos and/or doubtful geographical areas (Hijmans and Elith, 2017). In addition, spatial filtering was performed to select one occurrence in a $4.63 \times 4.63 \mathrm{~km}$ grid area, as bias might exist in records related to nearby herbaria, research institutes, and universities (Boria et al., 2014). We considered this spatial resolution because the study species has a geographically restricted distribution $(\mathrm{n}=$ 103 ), concentrated on regional mountains tops. A total of 43 occurrence grid cells remained after spatial filtering.

We considered 19 climatic variables - which were obtained from the WorldClim 1.0 database (Hijmans et al., 2005) - as explanatory variables of the geographical distribution of the species. We choose this version of WorldClim because it is the only version that provides future climatic conditions. These climatic variables were derived from monthly values of temperature and precipitation (averaged for 1961-1990), with the purpose of representing climatic conditions relevant for developing different life forms, in a grid of 2.5 minutes resolution $\left(\sim 4.63 \mathrm{~km}^{2}\right)$. The following variables were used: bio 1 (Annual Mean Temperature), bio 2 (Temperature Mean Diurnal Range), bio 3 (Isothermality), bio 4 (Temperature Seasonality), bio 5 (Maximum Temperature of Warmest Month), bio 6 (Minimum Temperature of Coldest Month), bio 7 (Temperature Annual Range), bio 8 (Mean Temperature of Wettest Quarter), bio 9 (Mean Temperature of Driest Quarter), bio 10 (Mean Temperature of Warmest Quarter), bio 11 (Mean Temperature of Coldest Quarter), bio 12 (Annual Precipitation), bio 13 (Precipitation of Wettest Month), bio 14 (Precipitation of Driest Month), bio 15 (Precipitation Seasonality), bio 16 (Precipitation of Wettest Quarter), bio 17 (Precipitation of Driest Quarter), bio 18 (Precipitation of Warmest Quarter), and bio 19 (Precipitation of Coldest Quarter). To remove problems related to multicollinearity of the climatic explanatory variables (Graham, 2003), the Variance Inflation Factor (VIF) values for these variables were determined. All values that were highly correlated (VIF $>10$ ) were removed through a stepwise procedure, using the vifstep $\mathrm{R}$ function from the usdm package (Naimi et al., 2014). Eight explanatory variables were used after accounting for multicollinearity (bio2, bio3, bio8, bio9, bio10, bio12, bio14, and bio18) (Figure 1). An elevation map with a grid of 2.5 minutes resolution was also extracted from WorldClim.

To predict how future climate changes will affect the distribution of $D$. angustifolia, we considered, for the year 2070 (average for 2061-2080), five atmospheric global circulation models (GCMs) (CCSM4, GISS-E2-R, ACCESS1-0, HadGEM2-AO, MIROC5). These GCMs are frequently used for predicting species distributions in South America (Yañez-Arenas et al., 2016; Graham et al., 2017) and they are part of the Coupled Model Intercomparison Project Phase 5 (CMIP5) of the IPCC Fifth Assessment. In addition, we considered two scenarios of climate change: RCP 4.5 (considered to be relatively less impactful) and RCP 8.5 (considered to be most impactful). In the low impact scenario (RCP 4.5), it is assumed that society will adopt measures to control greenhouse gas emissions. In the high impact scenario (RCP 8.5), it is assumed that humanity will not try to reduce the emission of greenhouse gases, which will consequently continue to increase. The climatic data for the projections for the listed climatic variables were obtained from WorldClim (Hijmans et al., 2005).

Modeling of the climate niche was performed using the Maximum Entropy algorithm (Maxent) (Phillips et al., 2017). For this approach-as recommended by Phillips and Dudík (2008) and Barbet-Massin et al. (2012) — we used a large number of pseudo-absences $(10,000)$ with no replication, which were distributed within $500 \mathrm{~km}$ radius buffers centered at each occurrence point. As we did not have independent data to test model accuracy (Pearson et al., 2007; Thuiller et al.,

Revista Árvore 2020;44:e4432 
bio 2 - Temperature Mean Diurnal Range $\left({ }^{\circ} \mathrm{C}\right.$

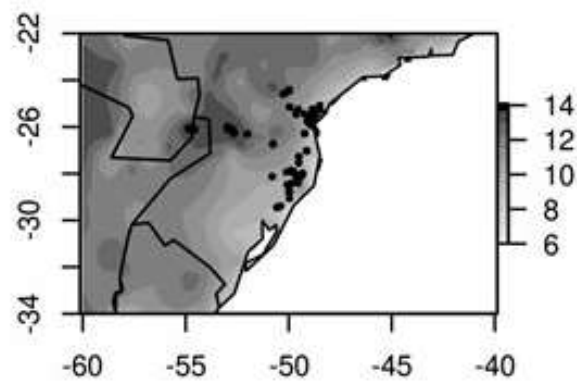

bio 8 - Mean Temperature of Wettest Quarter (" $\mathrm{C}$ )

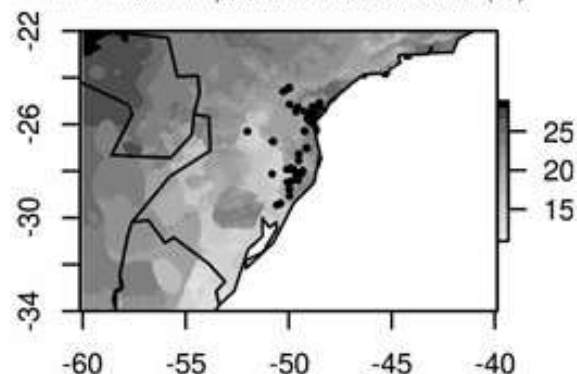

bio 10 - Mean Temperature of Warmest Quarter ("C)

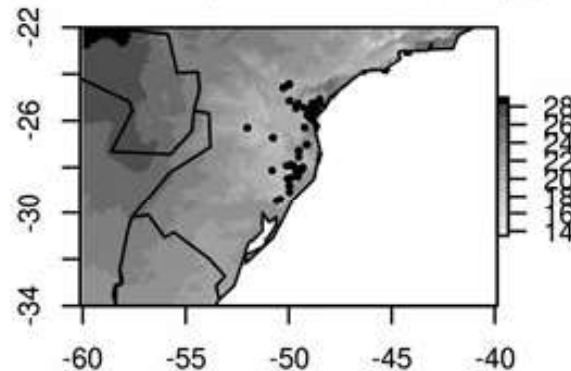

bio 14 - Precipitation of Driest Month (mm)

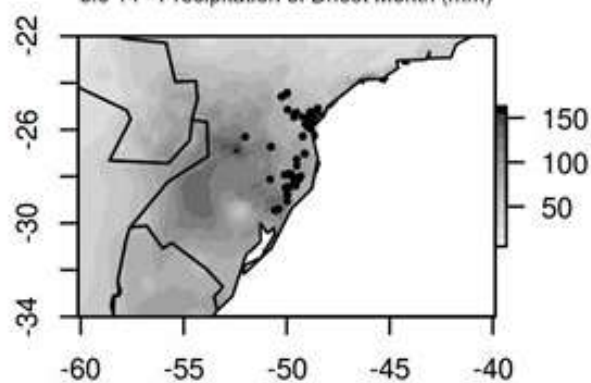

bio 3 - Isothermality ( $\%$ )

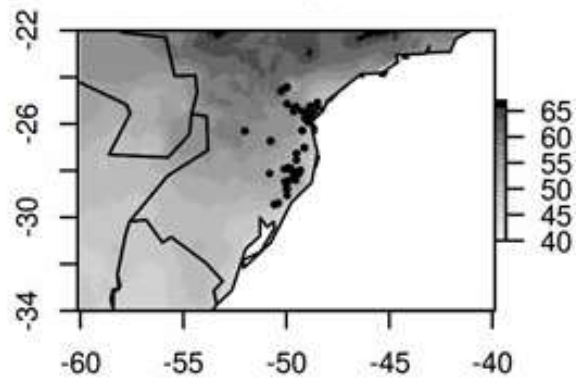

bio 9 - Mean Temperature of Driest Quarter ('C)

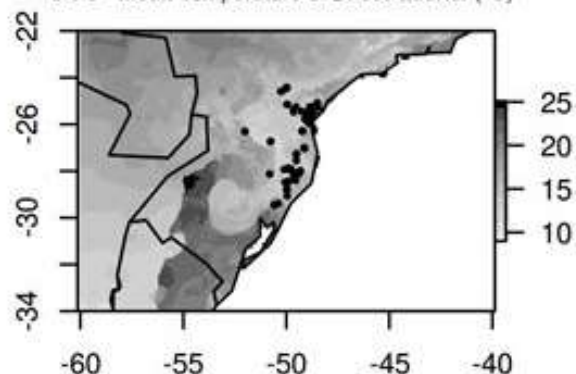

bio $12=$ Annual Precipitation $(\mathrm{mm})$

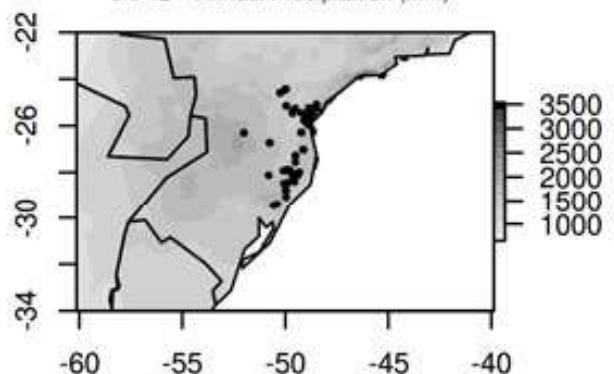

bio $18=$ Precipitation of Warmest Quarter $(\mathrm{mm})$

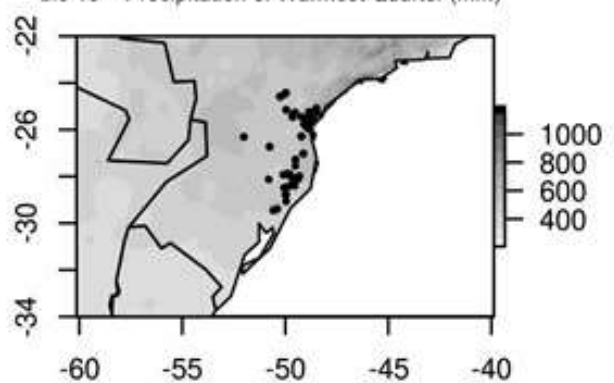

Figure 1 - Maps of climatic explanatory variables used in Drimys angustifolia distribution modeling. Darker gray shades represent higher values of bioclimatic variables. Black dots are the geographical occurrence of $D$. angustifolia.

Figura 1 - Mapas das variáveis explicativas climáticas utilizadas na modelagem Drimys angustifolia. Tons mais escuros de cinza representam maiores valores das variáveis bioclimáticas. Pontos negros indicam a ocorrência geográfica de D. nagustifolia.

Revista Árvore 2020;44:e4432 
2017), we evaluated model adjustment by splitting the data (presence plus pseudo-absence) into two groups: $70 \%$ randomly selected for model calibration (training) and the remaining $30 \%$ for model evaluation (testing) (Thuiller, 2003). This process of model evaluation was repeated five times and the performance of the adjusted models was evaluated through True Skill Statistics (TSS), with scores ranging from -1 to 1 (Allouche et al., 2006); the closer to 1 , the better the fit of the model. TSS is determined as sensitivity + specificity -1 , where sensitivity and specificity are, respectively, the proportion of correctly predicted presences and absences (Allouche et al., 2006). We adopted the classification of Landis and Koch (1977), in which TSS $\geq 0.75$ indicates adjustments of excellent performance, $0.40 \leq \mathrm{TSS}<$ 0.75 indicates adjustments with good performance, and TSS $<0.40$ indicates poor performance. Thus, based on the "evaluation strip" method proposed by Elith et al. (2005), which is an extension of other existing modelling techniques to be applied to raster data, we plotted response curves between the estimates of climatic suitability and the explanatory variables for the model adjustments. To reduce the inherent predictive uncertainty of adjustment in each individual model, current and future predictions (RCP 4.5 and RCP 8.5 ) of the potential geographic distribution of the species were performed using the consensus of all model adjustments that were classified with excellent performance (TSS $\geq 0.75$ ). This is an important step, as the uncertainty related to poor performance adjustments may result in unrealistic climate suitability projections.

To quantify the impact of different climate change scenarios, we produced a binary projection of potential areas of geographic occurrence, both for the present and future. We considered suitable areas based on ROC analysis. Current and future (RCP 4.5 and 8.5) projections were superimposed and areas of stable habitat (suitable currently and in the future), unstable future habitat (suitable only in the future), unstable current habitat (only suitable currently), and stable non-habitat were determined. All analyses were performed using $\mathrm{R}$ statistical programming language (R Core Team, 2017), with the usdm (Naimi et al., 2014), dismo (Hijmans et al., 2017), raster (Hijmans, 2017) and biomod2 (Thuiller et al., 2017) packages.

\section{RESULTS}

The geographic distribution of the studied species, D. angustifolia, is restricted to southern Brazil (Figure
$2 \mathrm{a}, \mathrm{b})$. In general, the areas where $D$. angustifolia is currently occurring will become more tropical, with higher temperatures and humidity, followed by a lower seasonality. (Table 1). Based on these adjustments and observed occurrence areas, high estimates of potential climate suitability were observed in high altitude areas, predominantly in southern Brazil, supporting the preference of $D$. angustifolia for climatic niches typical of upper-montane forest formations.

According to model adjustments with excellent performance (TSS $\geq 0.75$ ), the variables that best explained the climatic niche of D. angustifolia were Mean Temperature of Warmest Quarter (bio10), Precipitation of Driest Month (bio14), and Precipitation of Warmest Quarter (bio18). For these adjustments, the TSS ranged from 0.934 to 0.798 . D. angustifolia is more likely to occur in places where, during summer (warmer quarter), the average temperature does not exceed $19^{\circ} \mathrm{C}$, precipitation in the driest month exceeds approximately $100 \mathrm{~mm}$, and precipitation in the warmest quarter exceeds $700 \mathrm{~mm}$ (Figure 2c). Thus, the area of potential occurrence for $D$. angustifolia is characterized by summers with mild temperatures and an absence of dry periods.

When comparing the area of current climate suitability and the potential area according to the low (RCP 4.5, Figure 3) and high (RCP 8.5, Figure 4) impact scenarios, it is estimated that the potential area of occurrence of D. angustifolia will decline by an average of $68.24 \%( \pm 7.32 \%)$ and $79.15 \%( \pm 9.65 \%)$, respectively. These losses will mainly occur in areas of lower altitude. Unstable future habitat (suitable only in the future) did not exceed an average of $1.5 \%$ for either scenario.

\section{DISCUSSION}

The results of this study showed that the distribution of D. angustifolia is restricted mainly to southern Brazil, in the high altitude forests of this region. This geographic pattern is conditioned by the climatic niche of this species, which is characterized by mild temperatures and the absence of a dry season. This species is present at high abundance in cloudy upper-montane areas (Martins et al., 2012; Silva et al., 2017), suggesting that it has a high capacity to occupy this type of environment.

In relation to the impacts observed for the different scenarios of climate change, D. angustifolia should be

Revista Árvore 2020;44:e4432 

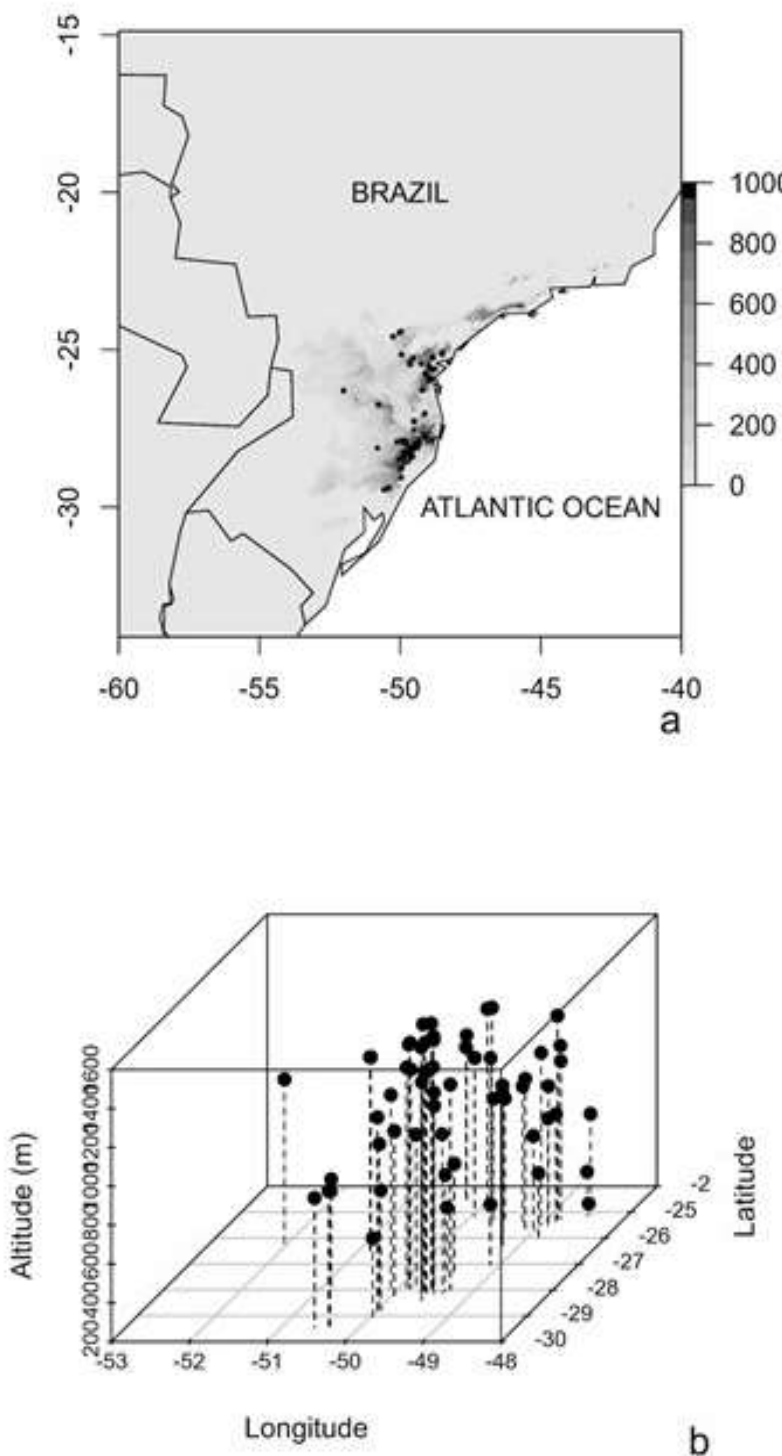
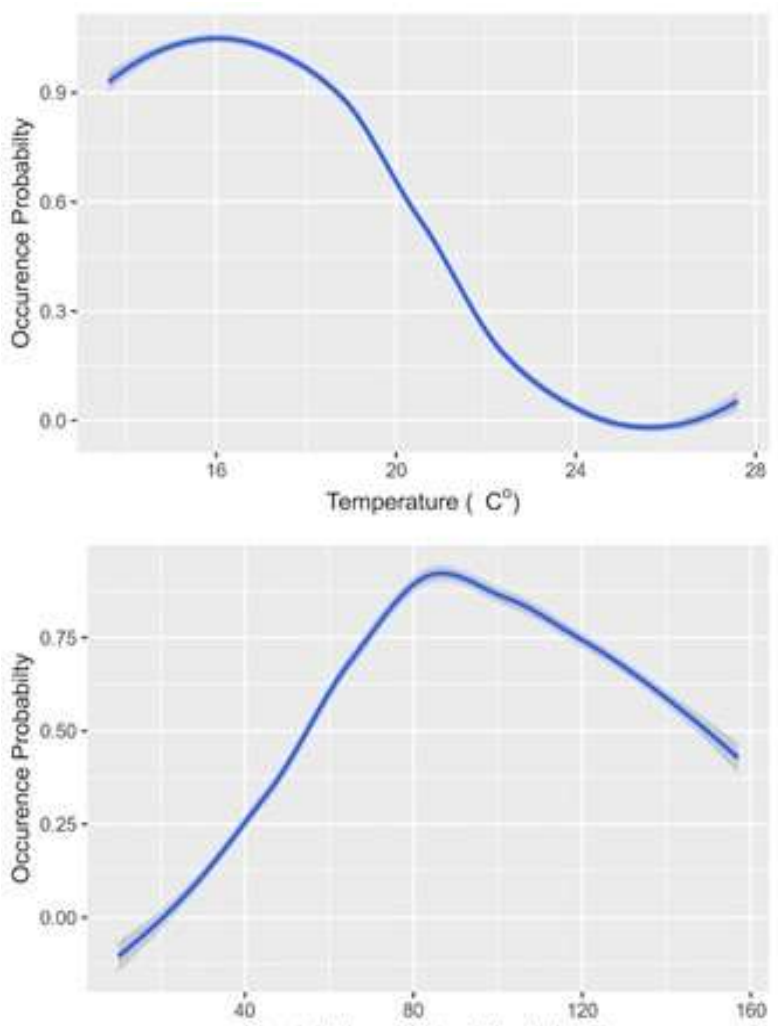

Precipitation of Driest Month (mm)

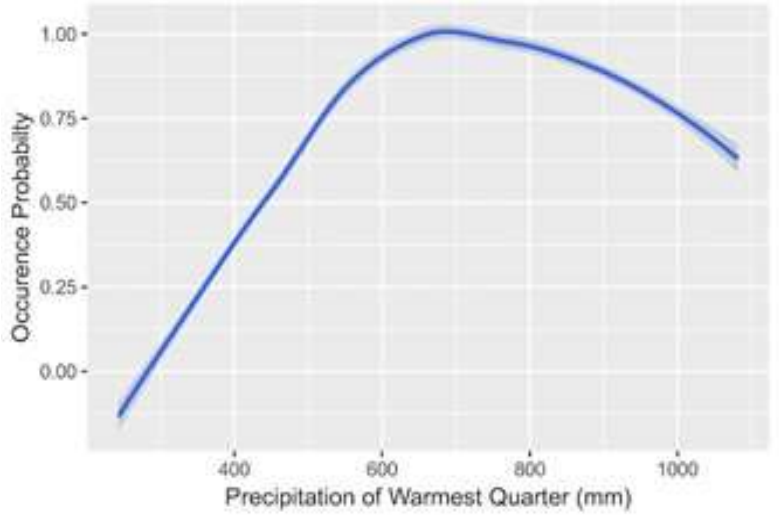

Figure 2 - Geographical distribution of Drimys angustifolia with (a) ensemble forecasting of species occurrence. (b) Three-dimension scatterplot of $D$. angustifolia occurrence, considering the latitude, longitude, and altitude. Shades of gray, from darker to lighter, represent the gradient of greater to lesser climatic suitability for the species (\%). (c) Probability of occurrence of $D$. angustifolia along the most significant climatic gradients [bio 10 - Mean Temperature of Warmest Quarter $\left({ }^{\circ} \mathrm{C}\right)$; bio 14 - Precipitation of Driest Month (mm); bio 18 - Precipitation of the Warmest Quarter (mm)].

Figura 2 - Distribuição geográfica de Drimys angustifolia com (a) a projeção de ocorrência baseada na probabilidade média de todos os ajustes do modelo que foram classificados com excelente desempenho (TSS $\geq 0,75$ ). (b) Gráfico dispersão tridimensional da distribuição geográfica de D. nagustifolia, considerando a latitude, longitude e altitude. Tons de cinza, de mais escuro para mais claro, representam o gradiente de maior a menor adequação climática para a espécie (\%). (c) Probabilidade de ocorrência de D. angustilofia ao longo dos gradientes climáticos mais significativos [bio 10 - temperatura média do trimestre mais quente $\left({ }^{\circ} \mathrm{C}\right)$; bio 14 - precipitação no mês mais seco $(\mathrm{mm})$; bio 18 - precipitação no trimestre mais quente $\left.(\mathrm{mm})\right]$.

Revista Árvore 2020;44:e4432 
Table 1 - Predicted future climate change (mean values and standard errors in parentheses) to occur in the region of Drimys angustifolia occurrence range, according to IPCC RCP 4.5 and RCP 8.5 scenarios (bio $2=$ Temperature Mean Diurnal Range; bio $3=$ Isothermality; bio $8=$ Mean Temperature of Wettest Quarter; bio $9=$ Mean Temperature of Driest Quarter; bio $10=$ Mean Temperature of Warmest Quarter; bio 12 = Annual Precipitation; bio 14 = Precipitation of Driest Month; bio $18=$ Precipitation of Warmest Quarter).

Tabela 1 - Previsões de mudanças climáticas futuras (valores médios e erros padrão entre parênteses) que ocorrerão na região do intervalo de ocorrência de Drimys angustifolia, de acordo com os cenários do IPCC RCP 4.5 e RCP 8.5 (bio $2=$ temperatura média diurna; bio 3 = isotermalidade; bio $8=$ temperatura média no trimestre mais úmido; bio $9=$ temperatura média no trimestre mais seco; bio 10 = temperatura média no trimestre mais quente; bio 12 = precipitação anual; bio $14=$ precipitação no mês mais seco; bio $18=$ precipitação no trimestre mais quente).

\begin{tabular}{lccc}
\hline & & Future $(2061-2080)$ \\
\hline Present & Change RCP 4.5 & Change RCP 8.5 \\
\hline bio 2 $\left({ }^{\circ} \mathrm{C}\right)$ & 10.89 & $-0.31(0.13)$ & $-0.13(0.07)$ \\
\hline bio 3 $(\%)$ & 55.10 & $0.96(0.53)$ & $-0.37(0.05)$ \\
\hline bio $8\left({ }^{\circ} \mathrm{C}\right)$ & 18.89 & $0.24(0.43)$ & $1.16(0.48)$ \\
\hline bio $9\left({ }^{\circ} \mathrm{C}\right)$ & 13.81 & $0.22(0.17)$ & $4.88(0.92)$ \\
\hline bio $10\left({ }^{\circ} \mathrm{C}\right)$ & 20.32 & $531.41(70.96)$ & $3.28(0.30)$ \\
\hline bio $12(\mathrm{~mm})$ & 1606.44 & $21.96(2.60)$ & \\
\hline bio $14(\mathrm{~mm})$ & 94.89 & $110.36(20.73)$ & $30.74(5.82)$ \\
\hline bio $18(\mathrm{~mm})$ & 484.78 & $178.72(25.13)$ \\
\hline
\end{tabular}

considered as a highly sensitive species, because the area of climatic suitability for this species was estimated to decline by 68 to $79 \%$, in response to a climate change towards more tropical conditions (warmer and wetter) in the future. Previous studies have shown that one of the responses of different terrestrial species to past and present climate change is to shift their distribution towards higher altitudes and latitudes (Chen et al., 2011; Hickling et al., 2006; Kelly and Goulden, 2008). However, for species already restricted to areas of higher altitude, such as D. angustifolia, this strategy is not possible, which renders these species more susceptible to the impacts of climate change, like the upper-montane ecosystem itself. In general, the results for D. angustifolia are in line with the patterns observed for some other species in the Araucaria Forest, which are found in lower altitudinal levels (Bergamin et al., 2019; Wilson et al., 2019; Marchioro et al., 2020). Climate changes predicted for this century will have a substantial impact on the whole forest formation, reducing the species climatic suitability area, which will tend to be restricted to places of higher altitude (Bergamin et al., 2019; Wilson et al., 2019; Marchioro et al., 2020). Given this critical scenario, there is an urgent need to undertake mitigation initiatives, such as in-situ (climate refuge protection) and ex-situ (germplasm banks) conservation strategies.

One should note that our findings must be understood only under the context of the species' climatic niche, a part of the fundamental niche. The understanding of the realized niche, beyond our scope in this study, would require further investigation of other factors. Besides the climate, other ecological factors play important roles in species distribution, such as biotic interactions (Wisz et al., 2013) and anthropogenic disturbances (Escobar et al., 2015). The negative effects of anthropogenic activities on terrestrial ecosystems, such as habitat fragmentation, are one of the main causes of species extinction (Tilman et al., 1994). If unsuitable areas (e.g., agriculture, cattle pasture, urbanization) are missed in distribution models, projected available areas could be overestimated. Furthermore, such chronic disturbances might result in the biological homogenization of forests (Ribeiro et al., 2015) and cannot be overlooked, because the fostering of pervasive and disturbance adapted species may give rise to a greater constraint on the occurrence of relatively less generalist ones. In southern Brazil, forests (including upper-montane cloud areas) have been subject to intense disturbances of this nature (e.g., fragmentation, selective logging, and cattle ranching) since the beginning of the 20th century, with deforestation peaking in the 1970s (Carvalho and Nodari, 2008). Considering this, it is reasonable to assume that both aspects have the potential to influence species distribution and neither should be neglected when planning conservation strategies.

\section{CONCLUSION}

The results of the present study showed that $D$. angustifolia and its associated ecosystem, the cloud forests of the southern portion of the Atlantic Forest in 

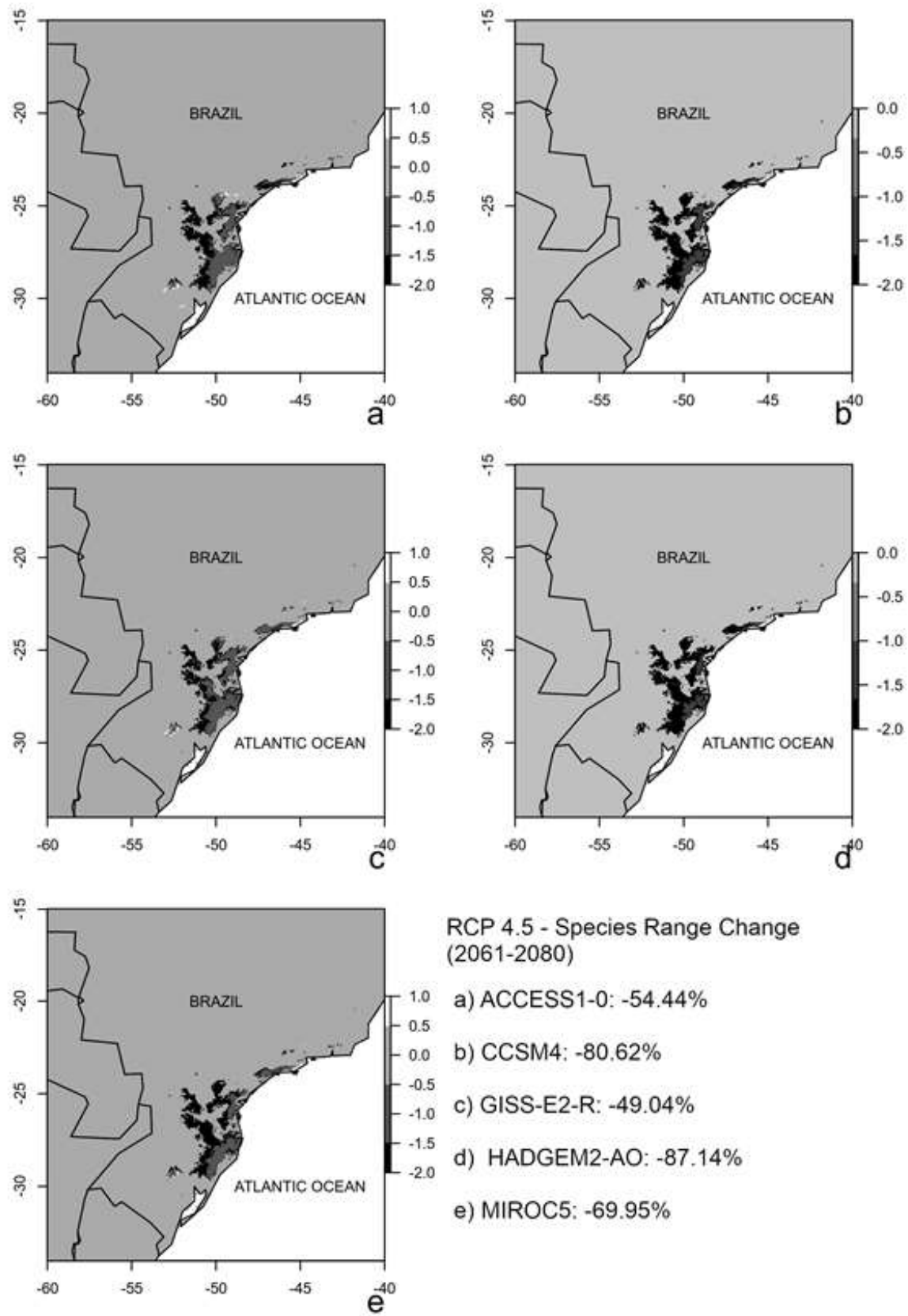

RCP 4.5 - Species Range Change (2061-2080)

a) ACCESS1-0: $-54.44 \%$

b) CCSM4: $-80.62 \%$

c) GISS-E2-R: $-49.04 \%$

d) HADGEM2-AO: $-87.14 \%$

e) MIROC5: $-69.95 \%$

Figure 3 - Future (2061-2080) climatically suitable areas for Drimys angustifolia, indicating the patterns of change for low (RCP 4.5) impact scenarios, according to five different atmospheric global circulation models (GCMs) (CCSM4, GISS-E2-R, ACCESS1-0, HadGEM2-AO, MIROC5). Dark gray = stable habitat (suitable both in current and future); light gray = stable non-habitat; black $=$ unstable current habitat (suitable only in current); white = unstable future habitat (suitable only in future).

Figura 3 - Áreas climáticas futuras (2061-2080) adequadas para Drimys angustifolia, indicando os padrões de mudança para cenários de baixo impacto (RCP 4.5), de acordo com cinco modelos diferentes de circulação global da atmosfera (GCMs) (CCSM4, GISSE2-R, ACCESS1-0, HadGEM2-AO, MIROC5). Cinza escuro = habitat estável (adequado tanto no presente quanto no futuro); cinza claro = habitat estável onde não há ocorrência da espécie; preto = habitat atual instável (adequado apenas no presente); branco = habitat futuro instável (adequado apenas no futuro).

Revista Árvore 2020;44:e4432 

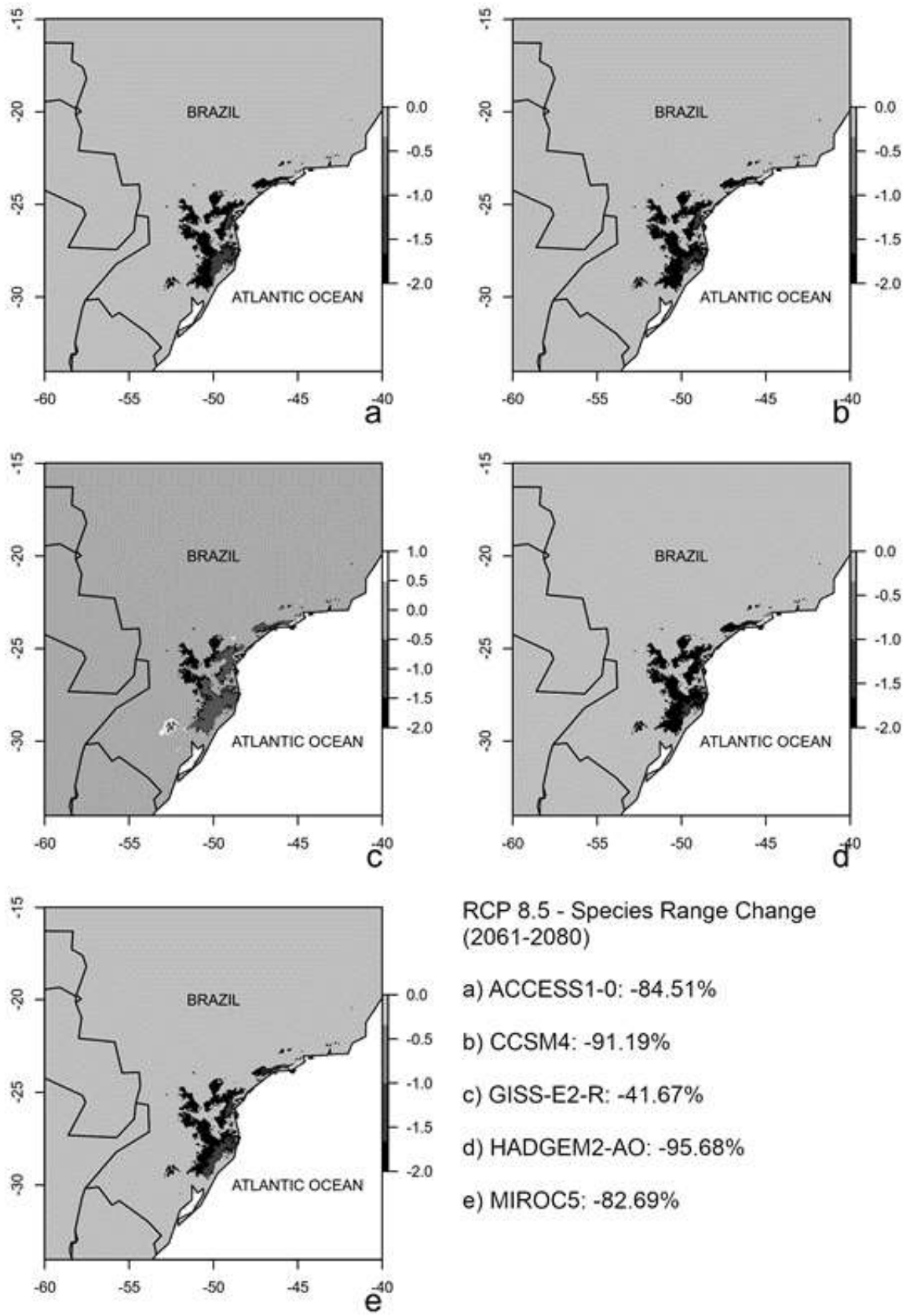

RCP 8.5 - Species Range Change (2061-2080)

a) ACCESS1-0: $-84.51 \%$

b) CCSM4: $-91.19 \%$

c) GISS-E2-R: $-41.67 \%$

d) HADGEM2-AO: $-95.68 \%$

e) MIROC5: $-82.69 \%$

Figure 4 - Future (2061-2080) climatically suitable areas for Drimys angustifolia, indicating the patterns of change under a low (RCP 8.5) impact scenario, according to five different atmospheric global circulation models (GCMs) (CCSM4, GISS-E2-R, ACCESS1-0, HadGEM2-AO, MIROC5). Dark gray = stable habitat (suitable both in current and future); light gray = stable non-habitat; black $=$ unstable current habitat (suitable only in current); white = unstable future habitat (suitable only in future).

Figura 4 - Áreas climáticas futuras (2061-2080) adequadas para Drimys angustifolia, indicando os padrões de mudança para cenários de baixo impacto (RCP 8.5), de acordo com cinco modelos diferentes de circulação global da atmosfera (GCMs) (CCSM4, GISSE2-R, ACCESS1-0, HadGEM2-AO, MIROC5). Cinza escuro = habitat estável (adequado tanto no presente quanto no futuro); cinza claro = habitat estável onde não há ocorrência da espécie; preto = habitat atual instável (adequado apenas no presente); branco = habitat futuro instável (adequado apenas no futuro) 
Brazil, are threatened by the potential impacts of future climate change. Consequently, we highlight climatically stable areas for the occurrence of $D$. angustifolia, such as those located in the highest parts of the mountain ranges of the southern and southeastern regions of Brazil, which should be considered as priority areas for protection and conservation as they are potential climatic refuges.

\section{ACKNOWLEDGMENTS}

The authors wish to thank Conselho Nacional de Desenvolvimento Científico e Tecnológico (CNPq) for granting a scholarship to GNS and a research productivity scholarship to ACS (Grant No. 309461/2014-6) and PH (Grant No. 456060/2014-6).

\section{REFERENCES}

Allouche O, Tsoar A, Kadmon R. Assessing the accuracy of species distribution models: prevalence, kappa and the true skill statistic (TSS). Journal of Applied Ecology. 2006;43(6):1223-32. doi: $10.1111 / \mathrm{j} .1365-2664.2006 .01214 . \mathrm{x}$

Barbet-Massin M, Jiguet F, Albert CH, Thuiller W. Selecting pseudo-absences for species distribution models: how, where and how many?. Methods in Ecology and Evolution. 2012;3(2):327-38. doi: 10.1111/j.2041-210X.2011.00172.x

Becker-Scarpitta A, Vissault S, Vellend M. Four decades of plant community change along a continental gradient of warming. Global change biology. 2019;25(5):1629-41. doi: 10.1111/gcb.14568

Bergamin RS, Debastiani V, Joner DC, Lemes P, Guimarães T, Loyola RD, et al. Loss of suitable climatic areas for Araucaria forests over time. Plant Ecology \& Diversity. 2019; 12(2):115-26. doi: 10.1080/17550874.2019.1618408

Boisvert-Marsh L, Périé C, Blois S. Divergent responses to climate change and disturbance drive recruitment patterns underlying latitudinal shifts of tree species. Journal of Ecology. 2019;107(4):195669. doi: 10.1111/1365-2745.13149

Boria RA, Olson LE, Goodman SM, Anderson RP. Spatial filtering to reduce sampling bias can improve the performance of ecological niche models. Ecological Modelling. 2014;275:73-77. doi: 10.1016/j.ecolmodel.2013.12.012
Carvalho MMX, Nodari ES. As origens da indústria madeireira e do desmatamento da floresta de araucária no Médio Vale do Iguaçu (1884-1920). Cadernos do CEOM. 2008;21(29):63-82.

Chen IC, Hill JK, Ohlemüller R, Roy DB, Thomas CD. Rapid range shifts of species associated with high levels of climate warming. Science. 2011;333(6045):1024-26. doi: 10.1126/ science. 1206432

Elith J, Ferrier S, Huettmann F, Leathwick JR. The evaluation strip: a new and robust method for plotting predicted responses from species distribution models. Ecological Modelling. 2005;186(3):280-89. doi: 10.1016/j.ecolmodel.2004.12.007

Escobar LE, Awan MN, Qiao H. Anthropogenic disturbance and habitat loss for the red-listed Asiatic black bear (Ursus thibetanus): Using ecological niche modeling and nighttime light satellite imagery. Biological Conservation. 2015;191:400-7. doi: 10.1016/j.biocon.2015.06.040

Foster P. The potential negative impacts of global climate change on tropical montane cloud forests. Earth-Science Reviews. 2001;55(1-2):73-106. doi: 10.1016/S0012-8252(01)00056-3

GBIF Secretariat. GBIF Backbone Taxonomy. Checklist Dataset 2017. doi: 10.15468/39omei accessed via GBIF.org on 15.04.2017

GBIF.org. GBIF Occurrence Download https://doi. org/10.15468/dl.xwx9ol Accessed from R via rgbif (https://github.com/ropensci/rgbif) on 2019-06-02; 2019.

Graham MH. Confronting multicollinearity in ecological multiple regression. Ecology. 2003;84(11):2809-15. doi:10.1890/02-3114

Graham LJ, Weinstein BG, Supp SR, Graham CH. Future geographic patterns of novel and disappearing assemblages across three dimensions of diversity: A case study with Ecuadorian hummingbirds. Biodiversity Research. 2017;23(8):944-54. doi: 10.1111/ddi.12587

Hertzog A, Pellegrini MOO, Santos-Silva F. Winteraceae do Rio Grande do Sul, Brasil. Rodriguésia. 2016;67(1):251-60. doi: 10.1590/21757860201667113

Revista Árvore 2020;44:e4432 
Hickling R, Roy DB, Hill JK, Fox R, Thomas CD. The distributions of a wide range of taxonomic groups are expanding polewards. Global Change Biology. 2006;12(3):450-55. doi: 10.1111/j.13652486.2006.01116.x

Higuchi P, Silva AC, Ferreira TS, Souza ST, Gomes JP, Silva KM, et al. Floristic composition and phytogeography of the tree component of Araucaria Forest fragments in southern Brazil. Brazilian Journal of Botany. 2012;35(2):145-57. doi:10.1590/ S0100-84042012000200004

Higuchi P, Silva AC, Almeida JA, Bortoluzzi RLC, Mantovani A, Ferreira TS, et al. Florística e estrutura do componente arbóreo e análise ambiental de um fragmento de Floresta Ombrófila Mista Alto-Montana no município de Painel, SC. Ciência Florestal. 2013;23(1):153-64. doi: $10.5902 / 198050988449$

Hijmans RJ, Cameron SE, Parra JL, Jones PG, Jarvis A. Very high resolution interpolated climate surfaces for global land areas. International Journal of Climatology. 2005;25(15):1965-78. doi: 10.1002/ joc. 1276

Hijmans RJ. Raster: Geographic Data Analysis and Modeling. R package version 2.3-40.2016. [cited 2017 Jul 9]. 2017. Available https://cran.r-project. org $/$ package $=$ raster

Hijmans RJ, Phillips S, Leathwick J, Elith J. Dismo: Species Distribution Modeling. R package version 1.0-12. 2015. [cited 2017 Jul 9]. 2017. Available https://cran.r-project.org/web/packages/dismo/index. html

Hijmans RJ, Elith J. Species distribution modeling with R.[cited 2017 Jul 9]. 2017. Available https:// cran.r-project.org/web/packages/dismo/vignettes/ sdm.pdf

Hoegh-Guldberg O, Hughes L, McIntyre S, Lindenmayer DB, Parmesan C, Possingham HP, et al. Assisted colonization and rapid climate change. Science. 2008;321(5887):345-6. doi: 10.1126/ science. 1157897

Instituto Brasileiro de Geografia e Estatística - IBGE. Manual técnico da vegetação brasileira. 2 ed. revista e ampliada. Rio de Janeiro: Fundação Instituto Brasileiro de Geografia e Estatística; 2012.
Intergovernmental Panel on Climate Change - IPCC. Climate Change 2001: Third Assessment Report of the Intergovernmental Panel on Climate Change IPCC (WG I \& II). Cambridge: Cambridge Univ. Press; 2001.

Intergovernmental Panel on Climate Change IPCC. Climate Change 2014: Synthesis Report. Contribution of Working Groups I, II and III to the Fifth Assessment Report of the Intergovernmental Panel on Climate Change. Geneva Switzerland: IPCC; 2014.

Kelly AE, Goulden ML. Rapid shifts in plant distribution with recent climate change. Proceedings of the National Academy of Sciences. 2008;105(33):11823-826. doi: 10.1073/ pnas.0802891105

Landis JR, Koch GG. The measurement of observer agreement for categorical data. Biometrics. 1977;33(1):159-74. doi: 10.2307/2529310

Martins D, Rodrigues AL, Chaves CL, Mantovani A, Bortoluzzi RLC. Estrutura de um remanescente de Floresta Ombrófila Mista em Urupema, Santa Catarina, Brasil. Revista de Ciências Agroveterinárias. 2012;11(2):126-37.

Marchioro CA, Santos KL, Siminski A. Present and future of the critically endangered Araucaria angustifolia due to climate change and habitat loss. Forestry. 2020;93(3):401-10. doi: 10.1093/forestry/ cpz066

Martínez ML, Pérez-Maqueo O, Vázquez G, Castillo-Campos G, García-Franco J, Mehltreter $\mathrm{K}$, et al. Effects of land use change on biodiversity and ecosystem services in tropical montane cloud forests of Mexico. Forest Ecology and Management. 2009;258(9):1856-63. doi: 10.1016/j. foreco.2009.02.023

Myers N, Mittermeier RA, Mittermeier CG, Fonseca GAB, Kent J. Biodiversity hotspots for conservation priorities. Nature. 2000;403(6772):853-8. doi: $10.1038 / 35002501$

Naimi B, Hamm NAS, Groen TA, Skidmore AK, Toxopeus AG. Where is positional uncertainty a problem for species distribution modelling? Ecography. 2014;37(2):191-203. doi: 10.1111/j.16000587.2013.00205.x

Revista Árvore 2020;44:e4432 
Pearson RG, Raxworthy CJ, Nakamura M, Peterson AT. Predicting species distributions from small numbers of occurrence records: a test case using cryptic geckos in Madagascar. Journal of Biogeography. 2007;34(1):102-17. doi: 10.1111/j.1365-2699.2006.01594.x

Phillips SJ, Dudík M. Modeling of species distributions with Maxent: new extensions and a comprehensive evaluation. Ecography. 2008;31(2):161-75. doi: 10.1111/j.09067590.2008.5203.x

Phillips SJ, Dudík M, Schapire RE. Maxent software for modeling species niches and distributions (Version 3.4.1). 2017. [cited 2017 Oct 18]. Available http://biodiversityinformatics.amnh.org/open_source/ maxent/

R Development Core Team. R: a language and environment for statistical computing. R Foundation for Statistical Computing. Vienna, Austria: R Foundation for Statistical Computing; 2017 . [cited 2017 Oct 18]. Available https://www.R-project.org/

Ribeiro EMS, Arroyo-Rodríguez V, Santos BA, Tabarelli M, Leal IR. Chronic anthropogenic disturbance drives the biological impoverishment of the Brazilian Caatinga vegetation. Journal of Applied Ecology. 2015;52(3):611-20. doi: 10.1111/13652664.12420

Silva AC, Higuchi P, Sobral MEG, Negrini M, Buzzi Júnior F, Bento MA, et al. Organização da comunidade e estrutura filogenética do componente arbóreo de um fragmento de Floresta Nebular no Planalto Catarinense. Ciência Florestal. 2017;27(1):129-41. doi: 10.5902/1980509826453

Thuiller W, Georges D, Engler R, Breiner F. Ensemble platform for species distribution modeling; R package version 3.3-7. [cited 2017 Oct 18]. 2017. Available https://CRAN.R-project.org/ package $=$ biomod 2

Thuiller W. BIOMOD - optimizing predictions of species distributions and projecting potential future shifts under global change. Global Change Biology. 2003;9(10):1353-62. doi: 10.1046/j.13652486.2003.00666.x

Tilman D, May RM, Lehman CL, Nowak MA. Habitat destruction and the extinction debt. Nature. 1994;371(6492):65-6. doi: 10.1038/371065a0

Uhlmann A, Gasper AL, Sevegnani L, Vibrans AC. Grupos florísticos estruturais da Floresta Ombrófila Mista em Santa Catarina. In: Vibrans AC, Sevegnani L, Gasper AL, Lingner DV (eds.). Inventário Florístico Florestal de Santa Catarina, Vol III, Floresta Ombrófila Mista. Blumenau: Edifurb; 2013. p. $145-153$.

Yañez-Arenas C, Peterson AT, Rodríguez-Medina $\mathrm{K}$, Barve N. Mapping current and future potential snakebite risk in the new world. Climatic Change. 2016;134(4):697-11. doi: 10.1007/s10584-015$1544-6$

Walther GR, Post E, Convey P, Menzel A, Parmesan C, Beebee TJC, et al. Ecological responses to recent climate change. Nature. 2002;416(6879):389-95. doi: $10.1038 / 416389 a$

Wilson AM, Jetz W. Remotely sensed highresolution global cloud dynamics for predicting ecosystem and biodiversity distributions. PloS Biology. 2016;14(3):e1002415. doi:10.1371/journal. pbio. 1002415

Wilson OJ, Walters RJ, Mayle FE, Lingner DV, Vibrans AC. Cold spot microrefugia hold the key to survival for Brazil's Critically Endangered Araucaria tree. Global change biology. 2019;25(12):4339-51. doi: $10.1111 / \mathrm{gcb} .14755$

Wisz MS, Pottier J, Kissling WD, Pellissier L, Lenoir J, Damgaard CF, et al. The role of biotic interactions in shaping distributions and realised assemblages of species: implications for species distribution modelling. Biological Reviews. 2013;88(1):15-30. doi: $10.1111 /$ j.1469-185X.2012.00235.x 